\title{
Performance of Eight Varieties of Onion (Allium cepa L.) Cultivated under Open Field in Tunisia
}

\author{
Ali ABDELKADER ABOU AZOOM, Kaouther ZHANI*, Chérif HANNACHI
}

Sousse University, Department of Horticulture and Landscape, Higher Institute of Agronomy, 4042, Chott Mariem, Tunisia: ali_abuazoom@yahoo.com; kaoutherzheni@yahoo.fr( ${ }^{*}$ correspondingauthor); hannachi_tnfr@yahoo.fr

\begin{abstract}
A field experiment was conducted from September 2010 to July 2011 at Research Station Farm of Higher Institute of Agronomy, Chott Mariem, Sousse (Tunisia) in order to evaluate the performance of seven onion varieties: 'GIZA 6', 'Red Amposta', 'Z6', 'Morada de Amposta', 'Yellow Dessex', 'Early Yellow Texas Grano 502' and 'Keep Red' against the commonly grown variety 'Blanc Hâtif de Paris' under field conditions. The experiment was conducted in a randomized complete block design with three replications. Results obtained showed that onion varieties were significantly different when it comes to the plant and bulb morphological characteristics. Variety 'Morada de Amposta' recorded the highest leaf length $(68.06 \mathrm{~cm})$, pseudostem diameter $(8.63 \mathrm{~cm})$, number of leaves $(8.71)$, plant height $(76.95 \mathrm{~cm})$, in addition to the greatest yields $(32.88 \mathrm{t} / \mathrm{ha})$ which were significantly $(\mathrm{p} \leq 0.05)$ increased by respectively 66.2, 88.8, 2.1, 61.2, 63, 27.9 and $28.4 \%$ compared to those obtained from the regular variety 'Blanc Hâtif de Paris'. Variety 'Blanc Hâtif de Paris' was the earliest to maturity and recorded the most preferment bulb weight $(155.02 \mathrm{~g})$ and diameter $(8.21 \mathrm{~cm})$. 'Keep Red' variety had the highest height of the bulb $(7.19 \mathrm{~cm})$. Variety ' $Z 6$ ' recorded the minimum data in all measured parameters.
\end{abstract}

Keywords: cultivars, growth, morphology, onion, production

\section{Introduction}

Onion (Allium cepa L.) is an important worldwide vegetable crop (Best, 2000) which belongs to the family of Liliaceae. It is divised into three groups: Allium cepa, Allium aggregattum, Allium prolilum, which are all diploids $(2 \mathrm{n}=$ $2 \mathrm{x}=16$ ) (Boukary et al., $2012 \mathrm{a}$ ). The crop is a biennial herb of Central Asian origin (Afghanistan, Iran and Pakistan) and is cultivated all around the world. Onion occupies the $4^{\text {th }}$ world rank of consumed vegetables after tomato, cabbage and watermelon with a global annual production of 25 million tonnes (Boukary et al., 2012a).

Tunisians appreciate onion for its distinctive flavor and it is considered as the most important crop in all condiments. It is daily used at immature and mature stage in salads, cooked or eaten raw as a vegetable. In Tunisia, the culture of onion is important and the country was classified in 2012 at the $7^{\text {th }}$ world rank with a production of 228600 MT (FAO STAT, 2012).

In fact, successful onion production depends mainly on the selection of varieties that are adapted to different conditions imposed by specific environment. In Tunisia, 'Blanc Hâtif de Paris' is the most popular variety grown by framers, both for home use and source of income. Therefore, the introduction of new varieties represents an important axe to enhance production by increasing the number of cultivars available for growers, which is not only an advantage for them but also for markets and processing industries.

Hence, the present research was conducted to evaluate performance of seven introduced varieties of common onion against the commonly grown variety 'Blanc Hâtif de Paris' with the objective of identifying the variety/varieties with a higher yield performance to replace or be used with the low yielding local variety under Tunisian field conditions.

\section{Material and Methods}

Field experiment was conducted in the experimental station (research farm) in Higher Institute of Agriculture of Chott Mariem, Sousse (Tunisia). The area is located on $35.8^{\circ} \mathrm{N}$ latitude and $10.6^{\circ} \mathrm{E}$ longitude, on the Easthern coastal part of Tunisia. The region belongs to semi-arid bioclimatic stage characterized by sweet winter and cool summer. Mean temperature varies from $11.4{ }^{\circ} \mathrm{C}$ (January) to $28{ }^{\circ} \mathrm{C}$ (August), annual rainfall recorded is above 300 $\mathrm{mm}$ and relative humidity ranges from 20 (December) to $80 \%$ (August). Direction of wind is North and NorthOuest with variable speed. The soil is sandy clay limestone and water is characterized by a $\mathrm{pH} 7$ and salinity of $1 \mathrm{~g} / \mathrm{l}$. The site into which the trial was conducted was previously cultivated with maize.

Seven onion varieties: 'GIZA 6' (G6) from Egypt, 'Red 
Amposta' (RA), 'Z6', 'Morada de Amposta' (MA) from Italy, 'Yellow Dessex' (YD) from Spain, 'Early Yellow Texas Grano 502' (G502), 'Keep Red' (KR) from America, were evaluated alongside the commonly cultivated variety in Tunisia "Blanc Hâtif de Paris" (BHP). They were studied for their growth and yield performance based on morphological and agronomical measurements.

The trial began on September 2010. Soil was cleared from weeds, rotovated and divised into seedbeds on which well-decomposed beef manure was applied and incorporated manually ( $360 \mathrm{~g}$ per plot) into the soil. Each seedbed $\left(110 \mathrm{~m}^{2}\right)$ was devised into three plots. Each plot contained the eight varieties in a randomized design. Two grams of seeds from each variety were sown on September $30^{\text {th }}$ in rows at spacing of $25 \mathrm{~cm}$ and a depth of $1 \mathrm{~cm}$ (every variety is represented by 15 rows). Irrigation was done manually using a fine watering. When seedlings began emergence, irrigation drip system was installed and used for irrigation and fertilization at an advanced stage. After seven weeks, only 10 seedlings spaced with $10 \mathrm{~cm}$ per row were left to record the observations. Weeding was done manually as needed and the fight against mildew and Alternaria was done chemically (copper: $400 \mathrm{~g} / \mathrm{hl}$ ). Harvesting took place when a large per cent of the leaves were dry and it lasted from April to July 2011 according to the variety.

Before studying the behaviour of the different cultivars, information about plant and bulb morphology in Tunisian climatic conditions were examinated according to TG/46/7 UPOV (2008) guidelines for Allium on 50 plants from each variety which were randomly chosen. Vegetative data included the number of leaves, fresh weight of leaves $(\mathrm{g})$, plant height $(\mathrm{cm})$, and plant weight $(\mathrm{g})$. Bulb characteristics concerned height $(\mathrm{cm})$, diameter $(\mathrm{cm})$, weight $(\mathrm{g})$ and number of axes. The parameters related to the shape, skin (colour, adherence and thickness), width of neck and position of maximal diameter was determined also following the TG/46/7 UPOV (2008) guidelines. Finally, yield $(\mathrm{t} / \mathrm{ha})$ was estimated and number of days to maturity from sowing were counted.

"SPSS software 13.00" was used to analyze the data and Duncan's multiple range test was used to separate the means at $5 \%(p<0.05)$.

\section{Results and Discussion}

The morphological characteristics of the eight varieties of onion cultivated under Tunisian climatic conditions concerned foliage and bulb and are presented in Tab. 1 and Tab. 2. Results showed a significant $(\mathrm{p}<0.05)$ variability between the varieties in all traits. The foliage postions was erect for BHP and G502 cv., semi-erect for 'YD', 'RA' and 'KR' cv. and erect to semi-erect for 'Z6', 'MA', and 'G6' cv. For leaf wariness, it was the same as for BHP cv. (weak) only in four varieties 'YD', 'G502', 'Z6' and 'G6'; for the others varieties, leaf had medium wariness. Also, leaf cranking, it was absent only in BHP and ' $\mathrm{ZG}$ ' cv. but intermediate in cultivars 'RA', 'MA' and 'KR' or strong in the three others genotypes. Green color of leaf in all new varieties was different from 'BHP' cv. (light). Two varieties had very light color ('MA' and 'Z6'), three had medium color ('G502', 'RA' and 'G6') and two were characterized by a dark color ('YD' and 'KR'). The measurement of diameter and length of leaf showed remarkable divergence among varieties. 'MA' $\mathrm{cv}$. had the highest length with 68.06 $\mathrm{cm}$ followed by 'YD' $(61.75 \mathrm{~cm})$ and 'KR' $(56.01 \mathrm{~mm})$ whereas ' $Z 6$ ' ( $35.5 \mathrm{~mm}$ ) and ' $\mathrm{G} 502$ ' (36.22 $\mathrm{mm}$ ) had the lowest values. Similarly, 'MA' had the largest leaf $(17.98$ $\mathrm{mm}$ ) followed by ' $\mathrm{KR}$ ' (16.01 mm) contrary to 'G502' cv. which showed the smallest diameter of $7.61 \mathrm{~mm}$. Concerning pseudostem, results demonstrated that its length ranged from 9.48 ('G502' cv.) to $16.35 \mathrm{~cm}$ ('RA' $\mathrm{cv}$.) and its diameter varied from 4.21 ('BHP' cv.) and 8.57 $\mathrm{cm}$ ('YD' cv.).

Stavělíková (2008) found similar results in foliage attitude in accessions of garlic and Ahmed et al. (2013) confirmed our finding on waxiness and cranking by studying the morphology of the 30 varieties of onion cultivated in Kashmir. Boukary et al. (2012a) studied the color of leaf on 21 Nigerian accessions of onion and indicated that 17 cultivars had green-gray leaf color whereas only four cultivars had green color. The same researchers observed also the difference in length of leafs which ranged from 17.08 ('JaI' cv.) to $41 \mathrm{~cm}$ ('BSn' cv.). Dela Rosa et al. (2005) also confirmed our results in leaf width which varied significantly between the 30 genotypes of rice characterized in Philippines. According to Nilufar (2009), the difference in foliage traits is mainly geneticly related to the cultivar.

In Tab. 2 are presented the morphological characteristics of the bulb of the eight studied varieties. Four shapes of bulb were observed which were different from 'BHP' cv. shape (Transverse narrow elliptic): circular ('YD' and 'RA'), rhombic ('Z6', 'G6' and 'KR'), broad ovate ('G502') and broad elliptic ('MA' cv.). Also, two colors of skin other than 'BHP' cv. grey color were detected: brown in 'MA' and 'Z6' skin and pink color in the other varieties. Among the eight genotypes, five had middle position of the maximal diameter ('YD', 'Z6', 'MA', 'KR' and 'G7'). For the rest, towards root end position was observed in bulb of 'BHP' and 'RA' cv. and towards stem end position in 'G502' cr. bulb. For thickness of skin, cultivars 'YD' and 'Z6' marked thick skin while 'BHP' and 'MA' varieties had thin skin. The other varieties maintained medium thick. The adherence of these skins was observed and results showed that it was medium in 'RA', 'MA' and ' $G 7$ ' cvs. whereas strong in all other varieties. For the width of bulb neck, it was very narrow only in ' $G 502$ ' cv. as for 'BHP' cv., narrow ('YD' and 'KR'), medium ('RA' and 'G6') and broad ('Z6' and 'MA'). According to statistical analysis, quantitative characteristics of bulb were significantly different $(\mathrm{p}<0.05)$ from one variety to another. Results in Tab. 2 showed that all genotypes had higher height but lower diameter compared to 'BHP' cv. Indeed, the biggest bulb of $8.21 \mathrm{~cm}$ diameter was noticed in 'BHP' cv. followed by ' $\mathrm{Z6}$ ' $(7.43 \mathrm{~cm})$ and ' $\mathrm{G} 6$ ' $(6.12 \mathrm{~cm})$, whereas 'KR' and 'MA' cvs. expressed the smallest diameter of bulb with 5.47 and $4.63 \mathrm{~cm}$ respectively. For height of the bulb, the highest value was observed in the case of 'KR' cv. (7.19 $\mathrm{cm})$ followed by 'YD' $\mathrm{cv}$. $(6.55 \mathrm{~cm})$ while the lowest one was in 'Z6' $(5032 \mathrm{~cm})$ and 'BHP' $(3.67 \mathrm{~cm})$.

Onion bulb is the widely consumed part of the plant, that is why its characteristics interested several works which insisted on the existence of genetic difference between the varieties of onion in diameter of neck (Gautam et al., 2006), skin thickness (Boukary et al., 2012a), color of skin (Currah 
Tab. 1. Foliage characteristics of eight varieties of onion cultivated under temperate conditions of Tunisian

\begin{tabular}{ccccccccc}
\hline Variety & $\begin{array}{c}\text { Foliage } \\
\text { attitude }\end{array}$ & $\begin{array}{c}\text { Leaf } \\
\text { waxiness }\end{array}$ & $\begin{array}{c}\text { Intensity of } \\
\text { green color }\end{array}$ & $\begin{array}{c}\text { Leaf } \\
\text { cranking }\end{array}$ & $\begin{array}{c}\text { Leaf } \\
\text { length } \\
(\mathrm{cm})\end{array}$ & $\begin{array}{c}\text { Leaf } \\
\text { diameter } \\
(\mathrm{mm})\end{array}$ & $\begin{array}{c}\text { Pseudostem } \\
\text { length } \\
(\mathrm{cm})\end{array}$ & $\begin{array}{c}\text { Pseudostem } \\
\text { diameter } \\
(\mathrm{cm})\end{array}$ \\
\hline BHP & Erect & Weak & Light & Absent & $40.96 \mathrm{~d}$ & $13.74 \mathrm{ab}$ & $15.25 \mathrm{~b}$ & $4.57 \mathrm{~d}$ \\
YD & Semi-erect & Weak & Dark & Strong & $61.75 \mathrm{ab}$ & $15.19 \mathrm{a}$ & $14.19 \mathrm{c}$ & $8.57 \mathrm{a}$ \\
\hline G502 & Erect & Weak & Medium & Strong & $36.22 \mathrm{~d}$ & $7.61 \mathrm{c}$ & $9.48 \mathrm{f}$ & $4.21 \mathrm{de}$ \\
RA & Semi-erect & Medium & Medium & Intermediate & $55.91 \mathrm{bc}$ & $14.86 \mathrm{ab}$ & $16.35 \mathrm{a}$ & $6.78 \mathrm{c}$ \\
Z6 & Erect to semi-erect & Weak & Very light & Absent & $35.50 \mathrm{~d}$ & $10.03 \mathrm{bc}$ & $13.84 \mathrm{~d}$ & $7.84 \mathrm{~b}$ \\
MA & Erect to semi-erect & Medium & Very light & Intermediate & $68.06 \mathrm{a}$ & $17.98 \mathrm{a}$ & $12.78 \mathrm{e}$ & $8.63 \mathrm{a}$ \\
\hline KR & Semi-erect & Medium & Dark & Intermediate & $56.91 \mathrm{bc}$ & $16.01 \mathrm{a}$ & $16.13 \mathrm{a}$ & $5.95 \mathrm{~d}$ \\
\hline G6 & Erect to semi-erect & Weak & Medium & Strong & $53.11 \mathrm{c}$ & $13.31 \mathrm{ab}$ & $14.58 \mathrm{bc}$ & $6.84 \mathrm{~cd}$ \\
\hline Means
\end{tabular}

Means in the same colone followed by the same letter are not significantly different at 5\% level according to Duncan test. RA: RedAmposta, MA: Morada de Amposta, YG: YellowDessex, KR: Keep Red, BHP: Blanc Hâtif de Paris, G502: Early Yellow Texas Grano 502

Tab. 2. Bulb morphological description of eight varieties of onion cultivated under temperate conditions of Tunisian

\begin{tabular}{|c|c|c|c|c|c|c|c|c|c|}
\hline Variety & $\begin{array}{l}\text { Height } \\
(\mathrm{cm})\end{array}$ & $\begin{array}{l}\text { Diameter } \\
(\mathrm{cm})\end{array}$ & $\mathrm{H} / \mathrm{D}$ & $\begin{array}{l}\text { Width of } \\
\text { neck }(\mathrm{mm})\end{array}$ & $\begin{array}{l}\text { Adherence } \\
\text { of skin }\end{array}$ & $\begin{array}{c}\text { Position of } \\
\text { maximal diameter }\end{array}$ & Shape & $\begin{array}{l}\text { Skin } \\
\text { colour }\end{array}$ & $\begin{array}{c}\text { Skin } \\
\text { thickness }\end{array}$ \\
\hline $\mathrm{BHP}$ & $3.67 \mathrm{f}$ & $8.21 \mathrm{a}$ & 0.44 & Very narrow & Strong & Towards root end & $\begin{array}{c}\text { Transverse narrow } \\
\text { elliptic }\end{array}$ & Grey & Thin \\
\hline YD & $6.55 \mathrm{ab}$ & $5.69 \mathrm{~d}$ & 1.15 & Narrow & Strong & At middle & Circular & Pink & Thick \\
\hline G502 & $6.09 c$ & $6.00 \mathrm{c}$ & 1.015 & Very narrow & Strong & Towards stem end & Broad obovate & Pink & Medium \\
\hline RA & $5.93 \mathrm{~cd}$ & $5.58 \mathrm{~d}$ & 1.06 & Medium & Medium & Towards root end & Circular & Pink & Medium \\
\hline Z6 & $5.32 \mathrm{e}$ & $7.43 \mathrm{~b}$ & 0.72 & Broad & Strong & At middle & Rhombic & Brown & Thick \\
\hline MA & $5.49 \mathrm{~d}$ & $4.63 \mathrm{e}$ & 1.18 & Broad & Medium & At middle & Broad elliptic & Brown & Thin \\
\hline $\mathrm{KR}$ & $7.19 \mathrm{a}$ & $5.97 \mathrm{~d}$ & 1.31 & Narrow & Strong & At middle & Rhombic & Pink & Medium \\
\hline G6 & $5.69 \mathrm{~d}$ & $6.12 c$ & 0.93 & Medium & Medium & At middle & Rhombic & Pink & Medium \\
\hline
\end{tabular}

Means in the same colon followed by the same letter are not significantly different at 5\% level according to Duncan test. RA: Red Amposta, MA: Morada de Amposta, YG: Yellow Dessex, KR: Keep Red, BHP: Blanc Hâtif de Paris, G502: Early Yellow Texas Grano 502

and Proctor, 1990) and adherence of skin (Ahmed et al., 2013). According to Anil (2008), onion bulb color is controlled at least by five major loci (I, C, G, L and R). Also, similar finding was obtained on onion between 18 genotypes in Spain (Rivera-Martinez et al., 2005), 10 genotypes in Bengladesh (Nilufar, 2009) and 21 ecotypes in Nigeria (Boukary et al., 2012b). Similarly, analogous data were founded for diameter and height of bulb by Moulin $e t$ al. (2012) working on different varieties of melon, tomato, pepper and potato.

The performance of the eight studied varieties was estimated by the determination of many parameters related to vegetative growth and productive stage. In all measurements, statistical analysis indicated the existence of a significant $(p<0.05)$ genetic difference between the varieties. The tallest plant was observed within the 'MA' cultivar $(76.95 \mathrm{~cm})$ followed by 'YD' $(70.55 \mathrm{~cm})$ whereas the smallest most dwarf plant was found within ' $\mathrm{Z} 6$ ', 'G502' and 'BHP' with a plant height of 42.61, 54.47 and $47.33 \mathrm{~cm}$ (Tab. 3). Similar variability in plant height between varieties confirming our results was observed on onion (Ibrahim, 2010; Trivedi and Dhumal., 2010). According to Mohanty and Prusti (2001), the difference in height of the plant on onion is mainly attributed to the genetic potential but also to environmental factors especially temperature and photoperiod (Tesfay et al., 2011). Also, the nutrients content in soil could be a cause in this difference in plant height, especially nitrogen and sulphur (Nasreen $e t$ al., 2007) which have been proved for their enhancement effect on the vegetative growth of onion.

For number of leaves/plant, 'YD' cv. produced the greatest number (9.36) whereas minimum number of

Tab. 3. Performance of onion cultivars cultivated under temperate conditions of Tunisia

\begin{tabular}{|c|c|c|c|c|c|c|}
\hline Variety & $\begin{array}{l}\text { Plant } \\
\text { height } \\
(\mathrm{cm})\end{array}$ & $\begin{array}{c}\text { Leaves } \\
\text { number }\end{array}$ & Bulb weight (g) & $\begin{array}{l}\text { Yield } \\
\text { (t/ha) }\end{array}$ & $\begin{array}{l}\text { Number } \\
\text { of axes }\end{array}$ & $\begin{array}{l}\text { Bulb maturation } \\
\text { (days after sowing) }\end{array}$ \\
\hline BHP & $47.73 \mathrm{~d}$ & $8.53 \mathrm{~b}$ & $155.02 \mathrm{a}$ & $25.600 \mathrm{~b}$ & $3 b$ & $156 c$ \\
\hline YD & $70.55 \mathrm{ab}$ & $9.36 \mathrm{a}$ & $98.55 \mathrm{de}$ & $24.875 \mathrm{~d}$ & $1.86 \mathrm{~cd}$ & $158 \mathrm{c}$ \\
\hline G502 & $45.41 \mathrm{~d}$ & $6.50 \mathrm{~d}$ & $101.63 \mathrm{~d}$ & $15.422 \mathrm{f}$ & $1.15 \mathrm{e}$ & $182 \mathrm{a}$ \\
\hline RA & $63.63 \mathrm{bc}$ & $6.13 \mathrm{~d}$ & $95.24 \mathrm{e}$ & $28.821 \mathrm{c}$ & $2 c$ & $168 \mathrm{~b}$ \\
\hline Z6 & $42.61 \mathrm{~d}$ & $5.43 \mathrm{e}$ & $63.16 \mathrm{f}$ & $13.037 \mathrm{~g}$ & $4 \mathrm{a}$ & $162 b c$ \\
\hline MA & $76.95 \mathrm{a}$ & $8.71 \mathrm{~b}$ & $139.25 \mathrm{~b}$ & $36.881 \mathrm{a}$ & $2 \mathrm{~cd}$ & $159 \mathrm{c}$ \\
\hline $\mathrm{KR}$ & $66.05 \mathrm{bc}$ & $7.86 \mathrm{c}$ & $110.43 c$ & $21.040 \mathrm{e}$ & $1.38 \mathrm{de}$ & $166 \mathrm{~b}$ \\
\hline G6 & $60.89 c$ & $6.23 \mathrm{~d}$ & $100.18 \mathrm{~d}$ & $21.157 \mathrm{e}$ & $1.76 \mathrm{~cd}$ & $161 \mathrm{c}$ \\
\hline
\end{tabular}

Means in the same colon followed by the same letter are not significantly different at 5\% level according to Duncan test. RA: Red Amposta, MA: Morada de Amposta, YG: Yellow Dessex, KR: Keep Red, BHP: Blanc Hâtif de Paris, G502: Early Yellow Texas Grano 502 
leaves/plant was noted in ' $\mathrm{Z} 6$ ' cr. whose plant produced a mean of 5.43 leaves/plant. Boukary et al. (2012a) and Dwivedi et al. (2012), observed the difference in production of leaves and leaf weight between varieties of onion and attributed this difference mainly to the cultivar, but other researchers confirmed that environmental conditions (Ijoyah et al., 2008) in which plant grown contribute to the development of leaves on plant.

Production results showed that the yield of onion varieties ranged from 15.42 to $36.88 \mathrm{t} / \mathrm{ha}$ and that some foreign varieties had slightly higher yield than that of the commercial variety 'BHP'. The Italian cultivar 'MA' was considered as the most productive variety with its best yield of $32.88 \mathrm{t} / \mathrm{ha}$. On the second place came the Italian cultivar 'RA' cv. (28.82 t/ha) and French cultivar BHP $c v$ on the third place $(25.6 \mathrm{t} / \mathrm{ha})$. On the fourth place came the Spanish cultivar YD with $24.87 \mathrm{t} / \mathrm{ha}$ ). However, the American cv. 'G502' and the Italian cv. 'Z6' had the lowest yield with 15.44 and $13.03 \mathrm{t} / \mathrm{ha}$.

Our finding agreed with the results of other researchers on onion in India (Mahanthesh et al., 2008), in Canada (Best, 2000), in Burkina Faso (Rouamba et al., 2001), in Cote d'Ivoire (Silué et al., 2003), in Nigeria (Kabura et al., 2008; Ibrahim, 2010). The recorded variations of varieties in marketable yield could be due to their differences in genetic make-up (Pavlovic et al., 2003) and/or agro ecological adaptations. Composition of growth media (Suthamathy and Seran, 2011), planting date (Hamma, 2013), degree of plant population (Kahsay et al., 2013) and other differences in cultural practices could also origin of variations in yield especially irrigation (Biswas et al., 2010) and fertilization (Brdar-Jakanovic et al., 2011). Khokar et al., (2002) reported also that the maximum temperature above $30^{\circ} \mathrm{C}$ and humidity (more than $80 \%$ ) enhance the reduction in onion yield.

The earliness in production was studied and 'BHP' cv. was the earliest variety because it took minimum days to produce bulbs ( 156 days after sowing) whereas ' $G 502$ ' was the last variety (182 days after sowing). Data of bulb weight indicated that 'BHP' cv. produced the biggest bulb of $155.02 \mathrm{~g}$ followed by MA (139.25 g) and KR (110.43 g), whereas ' $\mathrm{Z6}$ ' cv. had the minimum weight of bulb (63.13 g). Similar result was observed on others varieties of onion (Mohanty and Prusti, 2001; Mohanthesh et al., 2008; Trivedi and Dhumal, 2010; Dwivedi et al., 2012) and garlic (Volk, 2009). According to Soleymani and Shahrajabian (2012), bulb size could be affected by levels of nitrogen in soil. Also, Mishu et al. (2013) reported that amounts of sulphur had an impact on bulb weight of onion.

Bulb predominant number of axes varied considerably within each variety. Obtained results showed that this number ranged from 1.1 in G502 $c v$ to 4 axes in ' $\mathrm{Z} 6$ ' cv. Rivera-Martinez et al. (2005) and Ahmed et al. (2013) confirmed our result on 21 Spanish genotypes and 30 Indian varieties.

\section{Conclusion}

On the basis of present results, it can be concluded that the onion varieties studied can be easily differentiated from one another due to their distinctive morphological characters and their performance under Tunisian conditions. Therefore, the Italian varieties 'Morada de Amposta' and 'Red Amposta' and the Spanish one 'Yellow Dessex' could be maintained in Tunisian practices whereas the American cultivar 'Early Yellow Texas Grano 502' and the Egyptian one 'Giza 6' must be excluded. The study of the nutritional quality of the bulbs will be very interesting to make a better selection of varieties.

\section{References}

Ahmed N, Khan SH, Afroza B, Hussain K, Qadri S, Nazir G (2013). Morphological characterization in onion (Allium cepa L.) for preparation and implementation of plant variety protection (PVP) legislation and distinctness, uniformity and stability (DUS) testing under temperate conditions of Kashmir. African Journal of Agricultural Research 8(14):1270-1276.

Anil K (2008). Segregation for onion bulb colors reveal that red is controlled by at least three loci. J Am Soc Hort Sci 133:42-47.

Best K (2000). Red Onion Cultivars Trial. Horticultural Nova Scotia, Kentville Agricultural Centre, Nova Scotia (Canada):10-13.

Biswas SK, Khair A, Sarker PK, Alom MS (2010). Yield and storability of onion (Allium cepa L.) as affected by varying levels of irrigation. Bangladesh Journal of Agricultural Research 35(2):247-255.

Boukary H, Haougui A, Barage M, Adam T, Roumba A, et Saadou M (2012a). Evaluation agro-morphologique des variétés et/ou écotypes locaux d'oignon du Niger. Int J Biol Chem Sci 6(6):3098-3106.

Boukary H, Roumba A, Adam T, Barage M, Saadou M (2012 b). Interactions entre la variabilité des écotypes de l'oignon (Allium cepa L.) et les facteurs agro-climatiques au Niger. Tropicultura 30(4):209-215.

Brdar-Jokanović M, Ugrinović $M$, Cvikić D, Pavlović N, Zdravković J, Adžić S, Zdravković M (2011). Onion yield and yield contributing characters as affected by organic fertilizers. Field Veg Crop Res 48:341-346.

Currah L, Proctor FG (1990). Onions in tropical regions. Natural Ressources Institute Bulletin 35, NRI, UK, p 2321.

Dela Rosa A, Cadeya C, Hernandez JE, Gaspar MM, Masajo TM (2005). Agro-morphological characterization and purity assessment of mestizo-rice (PSB RC $72 \mathrm{H}$ ) from different seed sources. Philippine Journal of Crop Sciences 30(3):13-21.

Dwivedi YC, Kushwah SS, Sengupta SK (2012). Evaluation of onion varieties for growth, yield and quality traits under agroclimatic conditions of kymore plateau region of Madhya Pradesh, India. Agricultural Science Digest 32(4):326-328.

FAO STAT (2012). http://faostat.fao.org/site/339/default.aspx

Gautam SP, Khatri B, Paudel GP (2006). Evaluation of different varieties of onion and their transplanting times for off-season production in Mid Hills of Nepal. Nepal Agric Res J 7:21-26.

Hamma IL (2013). Growth and yield of onion as influenced by planting dates and mulching types in Samaru, Zaria. International Journal of Advance Agricultural Research 1:2226. 
224

Ibrahim ND (2010). Growth and yield of Onion (Allium cepa L.) in Sokoto, Nigeria Agric Biol J N Am 1(4):556-564.

Ijoyah MO, Rakotomavo H, Naiken MV (2008). Yield performance of four onions (Allium cepa L.) varieties compared with the local variety under open field conditions at Anse Boileau, Seychelles. Journal of Science and Technology 28(3):28-33.

Kabura BH, Musa B, Odo PE (2008). Evaluation of the yield components and yield of onion (Allium cepa L.) and pepper intercrop in Sudan savanna. Journal of Agronomy 7(1):88-92.

Kahsay Y, Belew D, Abay F (2013). Effect of intra-row spacing on yield and quality of some onion varieties (Allium cepa L.) at Aksum, Northern Ethiopia. Afr J Plant Sci 7(12):613-622.

Khokar KM, Mahmood T, Laghari MH (2002). Effect of Planting Dates on Bulb Yield. Vegetable Crops Journal 4:3-5.

Mahanthesh B, Ravi Prasad Sajjan M, Harshavardhan M, Vishnuvardhana, Janardhan G (2008). Evaluation of different onion (Allium cepa L.) genotypes for yield and processing quality parameters in Kharif season under irrigated condition. The Asian Journal of Horticulture 3(1):5-9.

Mishu HM, Ahmed F, Rafii MY, Golam F, Latif MA (2013). Effect of sulphur on growth, yield and yield attributes in onion (Allium cepa L.). AJCS 7(9):1416-1422.

Mohanty BK, Prusti AM (2001). Performance of common onion varieties in Kharif seasons. Journal of Tropical Agriculture 39:21-23.

Moulin MM, Rodrigues R, Gonçalves LSA, Sudré CP, dos Santos MH, da Silva JRP (2012). Collection and morphological characterization of sweet potato landraces in North of Rio de Janeiro state. Hortic Bras 30(2):286-292.

Nasreen S, Haque MM, Hossain MA, Farid ATM (2007). Nutrient uptake and yield of onion as influenced by nitrogen and sulphur fertilization. Bangladesh J Agri Res 32(3):413420.

Nilufar Y (2009). Morphological characterization and genetic diversity of onion (Allium cepa L.). Master's Thesis, Faculty of Agriculture, Sher-E-Bangla Agricultural University, Dhaka, $71 \mathrm{pp}$.

Pavlović N, Zečević B, Zdravković M, Ivanović M, Damjanović M (2003). Variability and heritability of average yield of onion bulb (Allium cepa L.). Genetika 35(3):149-154.
Rivera Martínez A, Fernández Paz J, Andrés Ares JL (2005). Evaluation of local onion lines from northwest Spain. Spanish Journal of Agricultural Research 3(1):90-97.

Rouamba Ghene RH, Bâ D, Ricroch A, Currah L (2001). Agronomic and physiological evaluation of some régional populations of onion in field and storage trials in West Africa Trop Sciences 41:78-84.

Silué S, Fondjio L, Coulibaly MY, Magein H (2003). Selection of onion varieties (Allium cepa L.) adapted to Côte d'Ivoire. Tropicultura 21(3):129-134.

Soleymani A, Shahrajabian MH (2012). Effects of different levels of nitrogen on yield and nitrate content of four spring onion genotypes. Intl J Agri Crop Sci 4(4):179-182.

Stavělíková H (2008). Morphological characteristics of garlic (Allium sativum L.) genetic resources collection Information Hort Sci (Prague) 35(3):130-135.

Suthamathy N, Seran TH (2011). Growth and yield response of red onion (Allium ascalonicum L.) grown in different potting media. Journal of Phytology 3(1):50-58.

Tesfay SZ, Bertling I, Odindo AO, Greenfield PL, Workneh TS (2011). Growth responses of tropical onion cultivars to photoperiod and temperature based on growing degree days. Afr. J. Biotechnol. 10(71):15875-15882.

Trivedi AP, Dhumal KN (2010). Variability and correlation studies on bulb yield, morphological and storage characters in onion (Allium cepa L.). Journal of Pure and Applied Sciences $18: 1-4$

UPOV (2008). Principes directeurs pour la conduite de l'examen de la distinction, de l'homogénéité et de la stabilité, Allium cepa (groupe Cepa), Allium cepa (groupe Aggregatum) et Allium oschaninii O. Fedtsch. et les hybrides entre eux. TG/46/7, Union Internationale pour la protection des obtentions végétales GENÈVE, 41 pp.

Volk GM (2009). Phenotypic characteristics of ten garlic cultivars grown at different North American Locations. Hortscience 44(5):1238-1247. 